\title{
Wrong Forms of some Yorùbá Personal Names: Some Phonological and Sociolinguistic Implications
}

\author{
Reuben Olúwáfẹ́mi Ì̀ọ̀tún (Adó-Èkìtì, Nigeria)
}

\begin{abstract}
In this study, we examine the wrong forms of some Yorùbá sentences that have become personal names through compounding. The data were extracted from the Joint Admissions and Matriculation Board (JAMB) lists of candidates that were considered for admission into three Nigerian Universities between the 2005 and 2010 academic sessions. The names extracted from that source were compared with names written in the staff lists of the three Universities in Nigeria. The wrongly written names were recorded on tapes and some native speakers were asked to listen to them to determine their correctness. We argue that wrong forms of some Yorùbá sentential/personal names are common occurrences and establish that they are traceable to the freedom granted by Yorùbá orthography developers. We also argue that, the confusion that results from the different spelling forms of some Yorùbá personal names is seriously observable in social interactions, labour market, schools or Colleges of Education/Universities, Embassies and Nigerian civil service both Federal and State and that court affidavits become imperative to authenticate or reconcile both the wrong and the correct forms for the purposes of admissions, appointments and overseas travelling documents. Similarly, we show that the position of the Yorùbá orthography developers has resulted in a loss of the actual pronunciation of some Yorùbá personal names which has severe implications for the semantic contents of the names as well as implications for the rich religious, cultural and philosophical heritage of the Yorùbá people.
\end{abstract}

\section{$1 \quad$ Introduction}

Research studies conducted by Samuel Ẹúndayọ̀ (1977: 55-77), Funṣọ Akinnásò (1980: 275-304), Solomon Oyètádé (1995: 532f.) and Reuben Ìkọ̀tún (2010a: 170-172, 2013: 7073) claim that a Yorùbá personal name can be a sentence which is a combination of a noun phrase and a verb phrase (NP+VP) or a noun phrase and a noun phrase (NP+NP) or a verb phrase (VP). Examples of a noun phrase and a verb phrase ( NP + VP) are as follows.

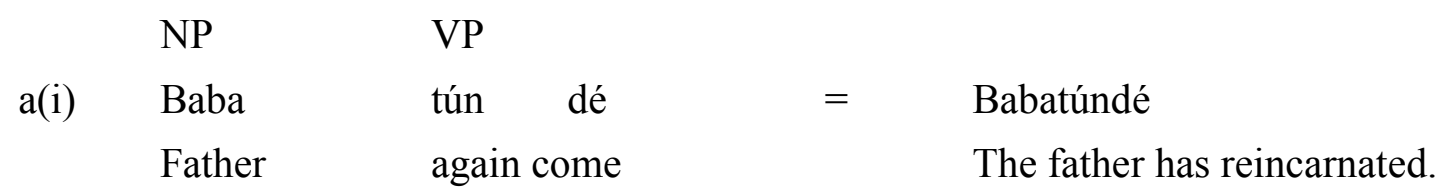


(ii)

\begin{tabular}{|c|c|c|}
\hline Ọmọ & rí adé yọ̀ & Ọmọrádéyọ̀ \\
\hline Child & see crown rejoice & $\begin{array}{l}\text { A child is happy because she has } \\
\text { seen a crown. }\end{array}$ \\
\hline
\end{tabular}

Some examples of a noun phrase and a noun phrase $(\mathrm{NP}+\mathrm{NP})$ also are indicated below.

$\begin{array}{lllll}\text { (iii) } & \text { Adé }+ & \text { ọlá } & = & \text { Adéọlá } \\ & \text { Crown } & \text { honour } & & \text { a crown of honour } \\ \text { (iv) } & \text { Ọ́á }+ & \text { Olúwa } & = & \text { Ọláolúwa } \\ & \text { Honour } & \text { Lord } & & \text { the Lord's honour }\end{array}$

In addition, verb phrase (VP) examples which are imperative sentences include the following

$\begin{array}{lllll}\text { (v) Jókòó } & \text { ti ọlá } & = & \text { Jókòótọlá } \\ & \text { sit } & \text { beside honour } & & \text { sit beside (by the side of) honour } \\ \text { (vi) Ja } & \text { ogun mú olú } & = & \text { Jagunmólú } \\ & \text { fight } & \text { war take honour } & \text { fight and conquer }\end{array}$

Writing on the social use of Yorùbá personal names, Solomon Oyètádé (1995: 532) reports that any Yorùbá sentential/personal name may appear in a full form, a shortened form or an initial form (cf. Lewis 2004: 311; Ìkọ̀tún 2010a: 170). For example, the name Jádesọlá can be realized as follows:

\begin{tabular}{|c|c|c|c|}
\hline$b(\mathrm{i})$ & $\begin{array}{l}\text { Jáde sí ọlá } \\
\text { go out to wealth }\end{array}$ & $=$ & $\begin{array}{l}\text { Jádesọ́lá } \\
\text { go in search of wealth }\end{array}$ \\
\hline \multirow[t]{2}{*}{ (ii) } & Jáde & $=$ & Jáde \\
\hline & go out & & go out \\
\hline \multirow[t]{2}{*}{ (iii) } & Sí ọlá & $=$ & Sọ́lá \\
\hline & to wealth & & to wealth \\
\hline \multirow[t]{2}{*}{ (iv) } & Olá & $=$ & Ọlá \\
\hline & wealth & & wealth \\
\hline \multirow[t]{2}{*}{ (v) } & Jáde sí ọlá & $=$ & $\mathrm{j}$ \\
\hline & go out to wealth & & initial form \\
\hline
\end{tabular}

In support of the social use of Yorùbá personal names, Reuben İkọttún (2010a: 175) advances four rules that can guide the shortening of Yorùbá sentential/personal names in social interactions and the rules are as follows:

Rule 1 Any Yorùbá personal name that has two syllables and which has not been reduced to initials should be retained as a name.

Rule 2 Any Yorùbá personal name that has three syllables and which has not been reduced to initials can be retained or reduced to the first two syllables or the last two syllables.

Rule 3 Any Yorùbá personal name that has four syllables and which has not been 
reduced to initials can be retained or reduced to either the first two syllables, the last three syllables or to the last two syllables.

Rule 4 Any Yorùbá personal name that has more than four syllables and which has not been reduced to initials can be retained or reduced to either the last two syllables, the last three syllables, two syllables that have semantic/cultural meaning(s) or have the first syllable deleted.

Reuben Ìkộtún (2010a: 171) also reports that some Yorùbá personal names are wrongly written in terms of present day orthography. For instance, where two syllables that have identical vowels occur together, only one syllable is written. Some examples are provided under groups A and B below.

\section{Group A: Correctly written}

Ọládipúpọ̀/Ọládiípọ̀

Ládipúpọ̀/Ládiípọ̀/Diípọ

Adéșeékẹ́

Àánú

Adéníkẹẹe

\section{Group B:Wrongly written}

Ọládipọ̀

Ládipọ̀/Dipọ̀

Adéșekẹ́

Ànú

Adéníkẹ

The correctly written names are derived as follows:

- by the deletion of $\{\mathrm{p}\}$; by assimilation between $\{\mathrm{i}\}$ and $\{\mathrm{u}\}$ and contraction: Ọlá di púpọ̀ $\rightarrow$ Ọlá di úpọ $\rightarrow$ Ọádiípọ

- by de deletion of $\{\mathrm{o}\}$ : Ọládiípọ̀ $\rightarrow$ Ládiípọ̀

- by reducing the name to the last three syllables: Ládiípọ̀ $\rightarrow$ Diípọ

- by the deletion of $\{\mathrm{k}\}$; by assimilation between $\{\mathrm{e}\}$ and $\{\mathrm{i}\}$ and contraction: Adé șe kíkẹe $\rightarrow$ Adé șe íkẹe > Adéșeékẹ

- by the deletion of $\{n\}$; by assimilation between $\{a\}$ and $\{\mathrm{i}\}$ : Ànínú $\rightarrow$ Àínú $\rightarrow$ Àánú

- by the deletion of $\{i\}$ and the assimilation of the low tone 'and contraction: Adé ní ìẹe $\rightarrow$ Adéníkẹẹ

According to Reuben Ìkộtún (2010a: 171), the forms under group B are used by many Yorùbá language writers whereas the forms under group A should be used. This is because the forms and the pronunciation of the names under group $\mathrm{A}$ agree with the current Yorùbá orthography. But it should be understood that the Yorùbá orthography has evolved over time and it has undergone reforms at different times. Our argument that $\mathrm{A}$ is the right form is based on the current orthography of Yorùbá language and the names under $B$ that are not in conformity with the current Yorùbá orthography are well understood by Yorùbá speakers especially those that are conversant with the old and current Yorùbá orthographic representations. However, the questions which seemed not to have been addressed in any research work are: (1) why are some Yorùbá personal names wrongly written? (2) are there 
consequences for the use of some Yorùbá personal names that allow odds between spelling and the Yorùbá sound system or that have inconsistent or contradictory spelling forms in social interactions? These questions will be addressed in this research work.

\section{Yorùbá Orthography}

Several attempts have been made by governments, organizations and scholars to design and bring Yorùbá orthography in line with actual speech (cf. Crowther 1852; Bowen 1858; Bámgbóṣé 1967, 1990; Afọlayan 1969; Oyèlárán 1971; Awóbùlúyì 1978; Akinlabí 1985; Owólabí 198; Ajíbóyè 2005, 2007). For example, in 1844, the Church Missionary Society (CMS) played a significant role through Bishop Ajayi Crowther to develop an orthography for the Yorùbá language (cf. Okediji et al. 197; Aróhunmọ́làșe 1987). In 1963 also, a seminar was organised at İbàdàn to address the problems that faced languages in Africa. Participants at the conference included some UNESCO members and they agreed that authors should use the spellings of the words written below in their writings (cf. A Report on Yorùbá Orthography 1969).

$\begin{array}{ll}\text { nwọn } & \text { they } \\ \text { aiyé } & \text { world } \\ \text { ẹ̀nyin } & \text { you } \\ \text { ọkùnrin } & \text { male } \\ \text { obìnrin } & \text { female } \\ \text { òn } & \text { he, she, it } \\ \text { àyà } & \text { wife } \\ \text { fún u } & \text { give him, her, it } \\ \text { rán a } & \text { send him, her, it } \\ \text { pín i } & \text { share it } \\ \text { wọn } & \text { them } \\ \text { ẹni ti } & \text { the person that } \\ \text { nigbagbogbo } & \text { every time } \\ \text { nitoripe } & \text { because } \\ \text { jẹki } & \text { let } \\ \text { wi pe } & \text { say that } \\ \text { wipe } & \text { that } \\ \text { ng } & \text { tense }\end{array}$

We can raise two questions from the 1963 committee's work.

- How could 'ayé' (world) which has Mid-High tone contour with two syllables of equal strength, duration and amplitude become 'aiyé' (world) a word, which has Mid-MidHigh tone contour with three syllables?

- How could vowels [u], [a], and [i], which are not nasal vowels replace nasal vowels in fún (give), rán (send) and pín (share) as pronouns in the object position? 
However, it must be pointed out that, in order to distinguish ayé 'world' from 'àyè' 'space' the committee recommended ayié for 'world'. But, they forgot that tones can do that. They also endorsed àiyà for 'chest' and aya for 'wife' for the same reason.

In January 1966, a committee was set up by the Western State of Nigeria to look into the possibility of recommending a Yorùbá orthography that would be standard for the whole region. In its recommendations, the committee resolved the linguistic ambiguity raised in question (b) and left the question (a) unanswered. They recommended the following (cf A Report on Yorùbá Orthography 1969: 50):

$\begin{array}{ll}\text { fún un } & \text { give him, her, it } \\ \text { pín in } & \text { share it } \\ \text { rán an } & \text { send him, her, it }\end{array}$

The enlarged committee on Yorùbá orthography of 1969 (by the Western State Government of Nigeria) introduced the use of hyphen into words that have nasal vowels (cf. A Report on Yorùbá Orthography 1969: 1f.). For example,

$$
\begin{aligned}
& \text { ọfọ́nọ̀n > ộfọ́n-ọ̀n 'a house rat' } \\
& \text { tiníntinín > 'tin-ín-tin-ín 'robin' }
\end{aligned}
$$

However, neither the 1963 committee nor the Western State of Nigeria committee discussed spelling and pronunciation norms of Yorùbá personal names.

The committee that succeeded in removing redundant letters which did not have any grammatical or lexical function in Yorùbá spellings was the committee set up by the Federal Government of Nigeria. This was in 1974 (cf. Joint Consultative Committee on Education (JCC) 1974/75: 1-18). For example, the use of vowel [i] which does not have any grammatical or lexical function in words like aiyé 'world', eiye 'bird', aiya 'wife' and a few others is discouraged. The committee also discussed spelling and pronunciation norms of Yorùbá personal names and argued in section 25 of the general clause of the Joint Consultative Committee on Education (JCC) (1974/75: 8) that:

The above recommendations should not necessarily apply to the spellings of personal names, not to poetry, dialectal transcriptions, dictionaries, grammars, and other technical writings, where authors should have the freedom to depart from the generally accepted orthography if the nature of their material or presentation compels them to do so. (JCC 1974/75: 8)

But, we can say that adherence to this clause in relation to personal names has resulted in a loss of the actual pronunciation of some Yorùbá personal names. Writing represents a permanent feature and whatever is written would remain for generations just as we now see wrongly written names in relation to modern Yorùbá orthography in books and official documents that have been written either in the past or now. It must be emphasized that the clause is totally at variance with accuracy; one of the principles of a good orthography. According to Kay Williamson (1984: 7), accuracy means that "an orthography must agree with the sound system of the language for which it is intended". Although, there are languages like English and French in which the spelling and pronunciation norms are at odds with this principle, this is not the case with Yorùbá. The Yorùbá spelling and the sound system must 
agree. For example, the Yorùbá spelling and the sound system endorse Oládipúpọ, Oládiípọ, Ládipúpọ, Ládiípọ and Diípọ (Riches have become many) as already discussed in the introductory section of this paper and not Oládipò, Ládipò, and Dipò which are commonly written and commonly used. The commonly written forms are not in agreement with the actual speech of the speakers of the language and therefore do not have lexical meaning.

Similarly, we are of the view that we should not trade freedom for accuracy and, even if the clause has not been revised or abrogated, the onus is on scholars to point out the negative effects of the freedom on the history of the Yorùbá language and Yorùbá culture. It would amount to a serious dereliction of duty if we just close our eyes to the confusion that results from the freedom granted by the JCC 1974/75. The confusion is seriously observable in social interactions, labour market, schools or Polytechnics/Colleges of Education/Universities, Embassies and Nigerian civil service both Federal and State. For example; there are instances of those who make serious attempts at correcting their names when wrongly pronounced by others, especially by Yorùbá youths whose competence in Yorùbá is not profound enough, based on the wrong forms in social interactions or in offices. Sometimes, the accusers (when older than the accused) may want to intimidate the accused by saying "İwọ ò kì í șe Yorùbá ni?" 'Are you not a Yorùbá person?'. Other people who may be around during the time of address will also show their disagreement. Some will laugh at the addressee. Some will pronounce the name correctly and expect the addressee to learn from such pronunciation and follow suit. Some will hiss and shake their heads and look at the addressee with disappointment. Some will even start to condemn the school system that kò sí ìwé mọ́ (there is no learning any more) while some will say: a ò tiẹ mo ohun tí wọ́n ń kọ́ ní school mọ 'we do not know what they are learning in the school any more'.

In addition, during registration exercise in the university, some newly admitted students are denied registration because of the inconsistencies in the spelling forms of their names or when the spelling forms of their names in their certificates do not tally with the spelling forms of the Joint Admissions and Matriculation Board (JAMB) lists. For example, if an applicant's name on his certificate reads Adékàmbí and that of the JAMB list reads Adékàńbi as they have been approved by Yorùbá orthography developers (though the correct spelling form is \{Adékànḿbi \} from Adé kàn mí bí? ('Am I also entitled to the throne/crown?'), after the deletion of vowel [i] and contraction), the registration officer will insist that Adékàmbí is not Adékàńbi because of the difference in the two consonants [m] and [n]. Questions such as: báwo ni orúko e șe yàtọ séyii tó wà lórí certificate e?? ('why is it that your name is different from the one that appears on your certificate?') are normally asked. The usual reply would be Ògá tó register wa fún WAEC ló kọ bẹẹ ('The master/teacher that registered us for WAEC wrote it like that'). There have been occasions where such candidates have been asked to either go to their former schools to get a letter correcting their names or to swear to an affidavit in a court that Adékàmbí is also Adékàńbí.

Similarly, Yorùbá candidates seeking admissions to higher institutions are not the only ones that face the problem of spelling errors. Yorùbá civil servants and Yorùbá travelers at Embassies too face the problem of spelling errors. For example, in the Nigerian Civil Service, verification exercise is done periodically by the Federal and State Ministries to determine ghost workers and ghost pensioners. Therefore, workers and pensioners who have the wrong 
forms of their names on their certificates tend to be complacent with the wrong forms for fear of being accused of falsification of certificates. There are also some who say Yorùbá òde òni kò tiẹ yé àwon ('The Yorùbá that is taught today is not clear to them'). Some of the people who claim ignorance of contemporary Yorùbá studies insist that the incorrect forms of their names should be used even when attempts to write the correct forms are put in place. Yorùbá travelers at Embassies also insist on the wrong forms that appear on their certificates and applications for visa otherwise the Embassies may turn down their applications or they may be asked to produce a court affidavit to support the differences in the spelling forms of their names.

Furthermore, it can be observed from the above review that the odds between the spelling and sound system of some Yorùbá personal names are caused by different Yorùbá orthographic representations that are not in agreement with the actual speech. In fact, wrong forms of some Yorùbá personal or sentential names occur right from the primary school level where the Yorùbá orthography that was in use then was not in conformity, in some cases, with actual speech. At the primary school, registration officers or teachers were, in the past, especially before independence, either Standard Six, Modern Three, Grade III or Grade II certificate holders, or in recent times, are either Grade II or NCE holders. These teachers learned the old Yorùbá orthography which was later revised. In the secondary school also, especially between the 60 s and early 80 s, secondary school principals would always deploy graduates of History and Geography to teach Yorùbá. The principals used to say "Șe bí Yorùbá ni" ('Afterall, it is just Yorùbá'), meaning that the teaching of Yorùbá does not require special training. So, the teachers' knowledge of Yorùbá phonological processes is very limited and this is as a result of the shortcomings identified in the Yorùbá orthography that was in use then. Some of those whose names have been wrongly written at the primary school level, based on the old orthography, later frowned at such spellings or forms after they have acquired sufficient training in Yorùbá at the University level especially after the 1974 revision of the Yorùbá orthography. Those who feel particularly worried about the wrong spellings or forms are the few ones who took their degrees in Yorùbá language at the University. The 1974/75 committee which had the opportunity of removing the odds between the spelling and sound system did not do so. Instead, the committee encouraged it. In the course of this paper, we will show also that the use of the wrong forms of Yorùbá personal names has severe implications for the semantic contents of the Yorùbá personal names as well as for the religious belief and philosophy of the Yorùbá people.

\section{$3 \quad$ Findings}

The data that were extracted from our findings are presented below. They are just some examples of the wrongly written names and they are sufficiently representative of the wrongly written Yorùbá personal names.
1. Ajéìgbé
Money act of lifting
2. Ọláitán
Wealth act of exhausting
3. Aládéibínú
The owner of crown anger
4. Fádójútìmí
Ifá put me to shame 


$\begin{array}{lll}\text { 5. } & \text { Fábùlújẹ́ } & \text { Ifá destroyed the town } \\ \text { 6. } & \text { Fáṣọ̀ràntì } & \text { Ifá found it difficult to solve problems } \\ \text { 7. } & \text { Fáyìnmínù } & \text { Ifá abandoned me } \\ \text { 8. } & \text { Fágbàmígbé } & \text { Ifá forgot me } \\ \text { 9. } & \text { Olásebìkan } & \text { Wealth dwells/stays in one place } \\ \text { 10. } & \text { Olówókéré } & \text { A rich person is not important } \\ \text { 11. } & \text { Akínmọ̀ìn } & \text { A valiant knows walk } \\ \text { 12. } & \text { Tanímọ̀wò } & \text { Who knows upbringing } \\ \text { 13. } & \text { Yemitàn } & \text { Do me not deceive } \\ \text { 14. } & \text { Awóseyìn } & \text { Cult do praise } \\ \text { 15. } & \text { Awóșekẹ́ } & \text { Cult do pamper } \\ \text { 16. } & \text { Oláníkẹ̀ } & \text { Riches have decay } \\ \text { 17. } & \text { Adéníkẹ̀ } & \text { Crown has decay }\end{array}$

However, as this discussion progresses we will show that the names listed above are sentences and that, at word boundary, they are wrongly derived and therefore, their semantic contents are not in consonance with Yorùbá cultural worldview.

\section{$4 \quad$ Analysis}

Deletion is a process in which a segment is lost, it is a robust phonological process in the Yorùbá language and Yorùbá language scholars that include Ayọ̀ Bámgbósée (1967: 6, 1990: 43), Ọládélé Awóbùlúyì (1978:149) and Francis Oyèbádé (1998: 63) among others have documented the process. In normal speech a vowel, a consonant or a lexical item may be deleted, e.g.

$$
\begin{array}{lll}
\text { 18(i) } & \text { Olú kò lọ } \rightarrow & \text { Olú ò lọ ('Olú did not go') } \\
\text { 18(ii) } & \text { Adé wá sí ilé } \rightarrow & \text { Adé wálé ('Adé came home') }
\end{array}
$$

The example in (18i) shows that the consonant [k] of the negative marker [kò] is deleted. The example in (18ii) indicates that the preposition [sí] is deleted and the vowel [i] of [ilé] (house) is also deleted. Despite the deletion of the items mentioned above, the surface forms in (i) and (ii) are grammatical and acceptable to native speakers. With regard to Yorùbá Personal Names (YPNs) also, one can observe deletion in both written and speech forms. Consider in this regard the following data. However, in the analysis that will follow we will show that the names that are grouped into five sections below are not correctly derived.

\section{Group one}
19. Ajéìgbé
Money act of lifting
20. Ọláitán
Wealth act of exhausting
21. Aládéibínú
The owner of crown anger 


\section{Group two}

22. Fádójútìmí

23. Fábùlújẹe

24. Fáṣọ̀ràntì

25. Fáyìnmínù

26. Fágbàmígbé

27. Ọláșebìkan

\section{Group three}

28. Olówókéré

\section{Group four}

$\begin{array}{lll}\text { 29. } & \text { Akínmọ̀ǹ̀n } & \text { A valiant knows walk } \\ \text { 30. } & \text { Tanímọ̀wò } & \text { Who knows upbringing } \\ \text { 31. } & \text { Yemitàn } & \text { Do me not deceive } \\ \text { 32. } & \text { Awóseyìn } & \text { Cult do praise } \\ \text { 33. } & \text { Awóṣekẹ } & \text { Cult do pamper }\end{array}$

\section{Group five}
34. Oláníkè
Riches have decay
35. Adéníkẹ̀
Crown has decay

In sentences 19, 20 and 21 below, the wrongly derived and used forms show that a segment [kí] of the habitual negative marker [kì í] is deleted, whereas it is only the consonant [k] that should be deleted. For example;

\section{Underlying Form}

19.

20.

Ajé kìi gbé
'Money is not spent in
vain'

Ọlá kìí tán

'Honour does not perish'

\section{Ajéìígbé \\ Ọláiítán}

Aládéííbínú

'A king (a crown owner) should not be angry'

\section{Correct Surface Form Wrong Surface and used Form}

Ajéìgbé

'Money act of lifting'

Ọláitán

'Wealth act of exhausting'

Aládéibínú

'The owner of crown anger'

Even where the bearers of the names and others write the names as wrongly derived above, the fact of the spoken form of the language clearly demonstrates that the wrongly derived forms do not accurately represent the spoken forms. 
There is a deletion of the negative marker [kò] thereby giving wrong written and used forms as compared with the spoken forms in sentences 22, 23, 24, 25, 26 and 27 below.

\section{Underlying Form}

22.

Fá kò dójú tìmí

'Ifá did not put me to shame'

23. Fá kò bàlú jẹ

'Ifá did not destroy the town'

24.

Fá kò șe ọ̀ràn tì
'Ifá can solve any
problem'

25. Fá kò yìn mí nù

'Ifá does not leave me alone'

26. Fá kò gbàmí gbé

'Ifá does not forget me'

27. Ọlá kò șebì kan

'Wealth does not do evil'

\section{Correct Surface Form}

Fáòdójútìmí/Fáàdójútìmí

Fáòbàlújẹe/ Fáàbàlújẹe

Fáòṣọ̀ràntì/Fáàṣọ̀ràntì

Fáòyìnmínù/Fáàyìnmínù

Fáògbàmígbé/Fáàgbàmígbé

Ọláòșebìkan/Ọláàșebìkan

\section{Wrong Surface and used Form}

\section{Fádójútìmí}

'Ifá put me to shame'

Fábùlújẹ

'Ifá destroyed the town'

Fáṣọ̀ràntì

'Ifá found it difficult to solve problems'

Fáyìnmínù

'Ifá abandoned me'

Fágbàmígbe

'Ifá forgot me'

Ọláșebikan

'Wealth dwells/stays in one place'

However, each of the correctly derived forms above has two options. The consonant $[\mathrm{k}[$ of the negative maker [kò] can be deleted in the first option. In the second option also, assimilation can occur between the vowels [a] and [o] after the deletion of the consonant [k] of the negative maker [kò].

In the sentence 28 below there is a deletion of the negative marker [kò] thereby giving wrong written and used form as compared with the spoken form which shows only the deletion of the consonant $[\mathrm{k}]$.

\section{Underlying Form}

28.

Olówó kò kéré
'The rich men are
important'

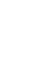

\section{Correct Surface Form}

Olówóòkére

\section{Wrong Surface and used Form}

Olówókére

'A rich man is not important'

One notes below the wrong deletion of segments like [rí] [wí] [tí] [yín] and [kí] in the wrongly derived and used forms in sentences 29, 30, 31, 32 and 33. Whereas what should be deleted are consonants $[\mathrm{r}],[\mathrm{w}],[\mathrm{t}],[\mathrm{y}]$ and $[\mathrm{k}]$. For example, 


\section{Underlying Form}

29.

Akín mọ rírìn
'A valiant person has
come at the right time'

30.

Ta ní mọ wíwò
'Who knows how to take
care of?'

31.

Ye mi títàn

'Do not continue to deceive me'

32. Awó șe yínyìn

33.

\section{Correct Surface Form}

Akínmọọónrìn

Tanímọọonwò

Yemiítàn

Awóseéyìn

Awóșeékẹ́

\section{Wrong Surface and used Form}

Akínmọ̀rìn

'A valiant knows walk'

Tanímọ̀wò

'Who knows

upbringing'

Yemitàn

'Do me not deceive'

Awóseyìn

'Cult do praise'

Awóṣekẹ́

'Cult do pamper'

However, the correctly derived forms in sentences 29 and 30 show the use of nasal vowel [0] after the deletion of consonants [r] and [w] and assimilation between [0]and [i]. The reason is that the consonant that occurs before the oral vowel [o] is a nasal consonant. In sentence 31, it is only contraction that occurs after the deletion of the consonant [t] while it is the case of assimilation between the vowels [e] and [in] in sentence 32 and [e] and [i] in sentence 33 and contraction after the deletion of consonants [y] and [k].

The sentences below show a deletion of the vowel of [ní]. There is also a relinking of the high tone of the deleted vowel to the initial vowel of the noun that occurs after the preposition [ní]. However, Ayọ̀ Bámgbóșé (1990: 46) reports that there is an assimilated low tone in Yorùbá which occurs where there is a deletion of one of two vowels at word boundary where the vowels bear $\mathrm{H}$ and $\mathrm{L}$ tones respectfully. The assimilated low tone is often disregarded in the written form, even when the spoken form reveals it; e.g.

\section{Underlying Form \\ Correct Surface Form}

34.

Ọlá ní ìkẹ

'Honour has care'

35.
Ọláníkẹẹ

Adéníkẹẹe

\section{Wrong Surface and used Form}

Ọláníkẹ̀

'Riches have decay'

Adéníkẹ

'Crown has decay'

\section{General Overview}

This paper has acknowledged the view of the 1974 committee on Yorùbá orthography in the area of freedom to write names as bearers deem fit. The concern of the present paper is the difference between the pronounced forms of Yorùbá personal names and the written forms. No doubt, this paper has demonstrated that linguistic items that are articulated in the spoken forms are omitted in the written forms. The question is: does the omission have any 
significant implication for the language? The answer is yes. The wrong forms have severe implications for the semantic contents of the names which in turn have implications for the religious belief and philosophy of the Yorùbá people. Talking about the religious implications, the rendering of the names in 23 where the good deeds. of Ifá (the Yorùbá god of wisdom) are misrepresented calls for serious concern. For example, we are told that Fáòbàlújẹ or Fáàbàlújẹ 'Ifá did not destroy the town' but the Yorùbá orthography developers endorse Fábùlújé 'Ifá destroyed the town'. The Yorùbá people see their gods as good intermediaries between them and their God. So, the Yorùbá people see the gods as reliable, responsible, efficient and always ready to assist in times of need. But, the freedom granted by the Yorùbá orthography developers presents the gods as unreliable and irresponsible. In fact, there may be a greater justification, apart from Christianity, for some Yorùbá people who change the noun phrases (NPs) of their names because of the bad image endorsed by the Yorùbá orthography developers.

Similarly, the underlying representations of names in 29 and 35 confirm previous findings that Yorùbá personal names, like other African names, are known to have elaborate linguistic structure and semantic contents (cf. Ekúndayọ̀ 1977: 55-77; Akínnásò 1980: 275-304, Adéníyì 2004: 149-157; İkộtún 2010a: 169-186, 2013: 68-73). For example, names like Akinmọọnrìn 'A valiant person has come at the right time' and Adénikẹée 'Crown has care' have linguistic structure and semantic contents. However, the surface representations or the wrongly derived forms of the data endorsed by the Yorùbá orthography developers are not in harmony with what African or Yorùbá personal names are known for and this position which shows odds between the spelling and sound system is not the best for understanding the linguistic structure and the rich cultural values contained in Yorùbá personal names.

\section{Conclusion}

We have examined the wrong forms of some Yorùbá sentences that have become personal names through compounding. We have argued that the wrong forms of some Yorùbá personal names are common occurrences and we have established that the wrong forms are traceable to the freedom granted by Yorùbá orthography developers. It has been argued also that the spelling and sound system of Yorùbá personal names are not at odds as it is the case in some other languages of the world and that the endorsement of the odds between the spelling and sound system of the wrong forms by Yorùbá orthography developers has resulted in a loss of the actual pronunciation of some Yorùbá personal names. This position whereby there are odds between the spelling and sound system of some Yorùbá personal names is not in harmony with what African or Yorùbá personal names are known for and it is not the best for understanding the linguistic structure and the rich cultural values contained in Yorùbá personal names.

\section{References}

Abíọ́dún, Michael A. (2010): "On the Gerundive Source of the Verb Infinitive Phrase in Yorùbá". In: Oyèbádé, Francis/Olúmúyìwá, Tộpẹ́ (eds.) (2010): New Findings in the Studies of Nigerian Languages and Literatures. A Festschrift in Honour of Oládélé Awóbùlúyì. Àkúré, Montem Paperback: 253-263. 
Adéníyì, Oládiípọ̀ R. (2004): "Meaning and Naming: Another Look at the Descriptive Theory of Names". Obitun: Journal of Humanities 3/3: 149-57.

Afọláyan, Adébísí (1969): "Some Neglected Aspects of Yorùbá Graphology". In: Banjo, Ayo et al. (eds.): Káàárọ Oòiíire, A Report on Yorùbá Orthography. İbàdàn, Ministry of Education: 21-25.

Ajíbóyè, Ọládiípọ̀ (2005): Topics on Yorùbá Nominal Expressions. Doctoral Dissertation, University of British Columbia, Vancouver.

Ajíbóyè, Ọládiípọ̀ (2007): "Òfin Aláyèmàyè Lààárín Fáwẹ̀lì Olóhùn Àárín àti Ìró Ohùn İsàlẹ̀ Nínú Àpọ́là Oníbàátan Lédè Yorùbá". Laangbasa 13: 6-17.

Akinlabí, Akin M. (1985): Tonal Underspecification and Yorùbá Tone. Unpublished Ph.D. Thesis, University of İbàdàn.

Akínnásò, Funșọ N. (1980): "The Sociolinguistic Basis of Yorùbá Personal Names". Anthropological Linguistics 22/7: 275-304.

Aróhunmọ́làșe, Oyèwọlé (1987): Àgbéyèwọ İdàgbàsokè Èdè àti Àkotọ́ Yorùbá láti Ọún 1800 sí 1985. Ìbàdàn: Oníbọnòjé Press \& Book Industries.

Awóbùlúyì, Oládélé (1978): Essentials of Yorùbá Grammar. Ìbàdàn: Oxford University Press.

Awóyalé, Yíwọlá (1983): "On the Development of the Verb Infinitive Phrase in Yorùbá".

Studies in African Linguistics 14/1: 71-102.

Bámgbósé, Ayọ̀ (1967): A Short Yorùbá Grammar. Ìbàdàn: Heinemann Educational Books.

Bámgbóséé, Ayọ̀ (1990): Fonọ́lọji àti Gírámà Yorùbá. Ìbàdàn: Ìbàdàn University Press.

Bánjọ, Ayọ̀ et al. (eds.) (1969): Káàárọ Oòjíire, A Report on Yorùbá Orthography. Ìbàdàn: Ministry of Education.

Bowen, Thomas J. (1858): Grammar and Dictionary of the Yorùbá Language. Washington DC: Swithsonian Institute.

Chomsky, Noam/Halle, Morris (1968): Sound Pattern of English. New York: Harper and Row.

Crowther, Samuel A. (1852): A Grammar and Vocabulary of the Yorùbá Language. London: Seelay's.

Ekúndayọ̀, Samuel A. (1977): "Restrictions on Personal Name Sentences in the Yorùbá Noun Phrase". African Linguistics 19: 55-77.

Ìkọ̀tún Reuben O. (2010a): "The Social Use of Yorùbá Personal Names". Names 58/3: 169186.

Ìkộtún, Reuben O. (2013): "New Trends in Yorùbá Personal Names among Yorùbá Christians". Linguistik Online 59: 65-83.

Joint Consultative Committee (JCC) (1974/75): 1974 Revised Official Orthography for The Yorùbá Language. Lagos: Federal Ministry of Education.

Lewis, Démọ́lá (2004): "A Constraint Based Analysis of Nominal Clips in Yorùbá". In: Owólabí Kọ́lá/Dasylva Adémọlá (eds.) (2004): Forms and Functions of English and Indigenous Languages in Nigeria. A Festschrift in Honour of Ayọ Bánjọ. İbàdàn, Group Publishers: 296-312.

Òkédijí, Olú F. et al. (1970): The Sociology of the Yorùbá. Ìbàdàn: University Press.

Owólabí, Kộlá (1989): İjìnlè İtúpalẹ Ėdè Yorùbá Fònẹtiiki àti Fonọlọjì. Ìbàdàn: Onibọnoje Press \& Book Industries.

Oyèbádé, Francis (1998): A Course in Phonology. İjẹbú-Òde: Shebiotimo Publications. 
Oyèláràn, Ọlasọpe O. (1971): Yorùbá Phonology. Unpublished Doctoral Dissertation, Stanford University.

Oyètádé, Solomon O. (1995): "A Sociolinguistic Analysis of Address Forms in Yorùbá". Language in Society 24/4: 515-535.

Șówándé, Fẹlá/Àjànàkú, Fágbèmí (1969): Orúko Amútọrunwá. Ìbàdàn: Oxford University Press.

Williamson, Kay (1984): Practical Orthography in Nigeria. Ibadan: Heinemann Educational Books. 